\title{
DESCRIPTIONS OF NEW TROCHOID SHELLS FROM NORTH QUEENSLAND.
}

By H. B. Preston, F.Z.S.

Read 11th June, 1909.

LEPTOTHYRA CRASSILIRATA, n.sp.

Shell somewhat globosely turbinate, solid, dark purplish-red; whorls $4 \frac{1}{2}$, sculptured throughout with coarse, rather broad liræ; sutures impressed; columella descending in a very oblique curve; peristome acute; aperture subcircular; operculum unknown. Alt. $7 \cdot 25$, diam. maj. $7.5 \mathrm{~mm}$; aperture, alt. 4 , diam. $3 \mathrm{~mm}$.

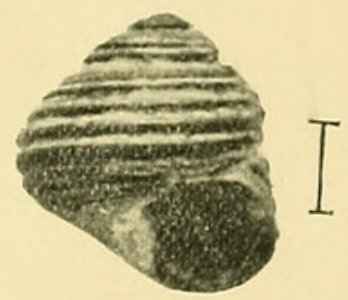

Hab.-North Queensland.

As the present shell has all the appearance of that of a Leptothyra, I have placed it provisionally in that genus, notwithstanding the fact that the operculum is unknown. In many respects it resembles L. sanguinea, Linn., but is easily separable from that species by the much coarser basal sculpture.

\section{Gibbela Dacostana, n.sp.}

Shell perforate, turbinate, moderately solid, blackish bronze, tesselated with cream colour, and flecked and spotted, especially on the base, with the same colour, alternating with rusty red; whorls $5 \frac{1}{2}$, rather coarsely spirally lirate, the interstices between the liræ bearing two fine spiral striæ; sutures impressed; umbilicus narrow, deep,

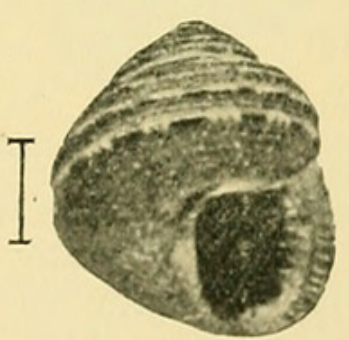

the umbilical region being somewhat lighter in colour than the rest of the shell; columella curved; peristome iridescent bluish green, minutely dentate throughout, the margins joined by a thickish pearly callus; aperture subquadrate; operculum horny, multispiral. Alt. 8 , diam. maj. $8 \mathrm{~mm}$; ; aperture, alt. 4.25 , diam. $3.25 \mathrm{~mm}$.

Hab.-North Queensland.

VOL. VIII.-SEPTEMBER, 1909. 
I have great pleasure in dedicating this species to the memory of my friend, the late Mr. S. I. Da Costa, from whose collection it originally came.

\section{Gibbula tenoilirata, n.sp.}

Shell turbinate, chocolate, tesselated and sparsely spotted with cream colour; whorls 5, sculptured with many fine, closely-set liræ, and minute, oblique, transverse striæ, presenting under a lens a lightly cancellate appearance; sutures impressed; umbilicus moderately narrow; columella descending obliquely and somewhat sinuously,

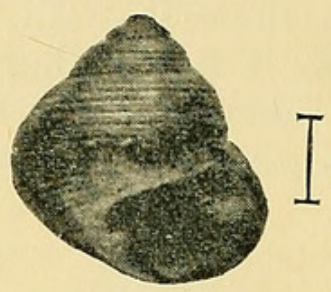

slightly outwardly expanded above orer the umbilicus; peristome acute, the margins joined by a whitish callus; aperture subcircular; interior of shell white. Alt. 7, diam. maj. $7 \mathrm{~mm}$.; aperture, alt. 4, diam. $3 \mathrm{~mm}$.

$$
\text { Hab.-North Queensland. }
$$

\section{Minolia cinerea, n.sp.}

Shell roundly turbinate, shining, grey, painted above with closelyset transverse bands of greyish-brown; whorls $6 \frac{1}{2}$, flattened above, sculptured with a number of beaded carinæ, increasing to four on the last whorl, the space above these occupied by two spiral beaded riblets, a third also occurring between the first and second carinæ; sutures impressed; base of shell sculptured with two spiral grooves and a number of very fine spiral striæ, painted with a zone of fine,

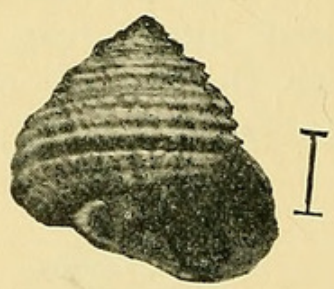

closely-set cinereous flammules, within which is a second zone almost uniformly of the same colour; umbilicus whitish, wide, deep, bearing several small, indistinct, spiral, crenate riblets, the outer margin surrounded by a coarsely crenulate carina; columella somewhat angularly arched above, descending obliquely and terminating rather abruptly; peristome acute; aperture subquadrate. Alt. 6.75, diam. maj. $6.5 \mathrm{~mm}$.; aperture, alt. 3 , diam. $2 \mathrm{~mm}$.

Hab.-North Queensland.

It is very difficult to give anything like an adequate description of the complicated sculpture and colouring of this interesting form, and I do not know of any species to which it may be protitably compared. 

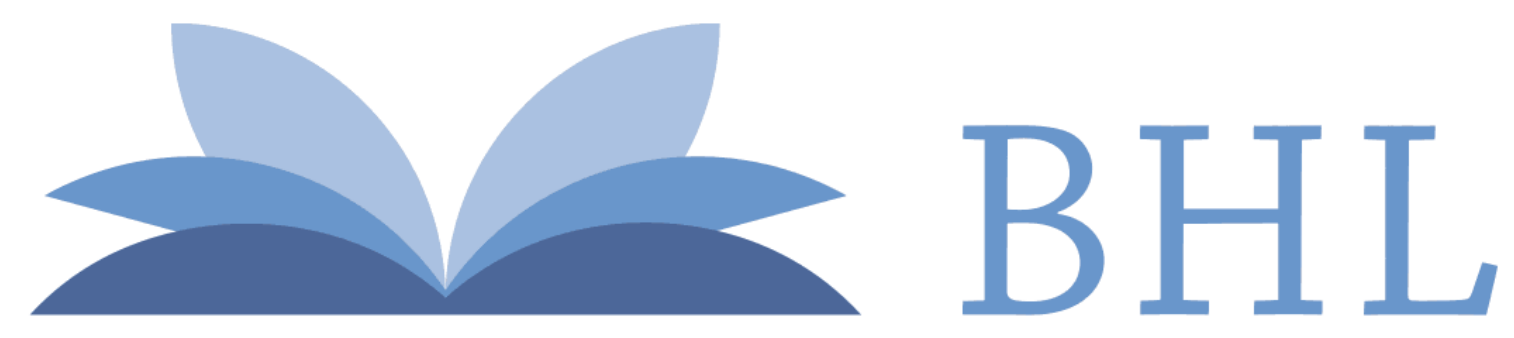

\section{Biodiversity Heritage Library}

Preston, H B. 1909. "DESCRIPTIONS OF NEW TROCHOID SHELLS FROM NORTH

QUEENSLAND." Proceedings of the Malacological Society of London 8, 377-378.

View This Item Online: https://www.biodiversitylibrary.org/item/100060

Permalink: https://www.biodiversitylibrary.org/partpdf/203017

\section{Holding Institution}

Field Museum of Natural History Library

\section{Sponsored by}

Smithsonian

\section{Copyright \& Reuse}

Copyright Status: Public domain. The BHL considers that this work is no longer under copyright protection.

This document was created from content at the Biodiversity Heritage Library, the world's largest open access digital library for biodiversity literature and archives. Visit BHL at https://www.biodiversitylibrary.org. 